JMKSP (Jurnal Manajemen, Kepemimpinan, dan Supervisi Pendidikan)

Volume 7 Issue 1 (2022) Page 328-336

ISSN 2614-8021 (Online) 2548-7094 (Print)

\title{
Need Analysis of Developing Digital Teaching Materials Based on MOOCs for Postgraduate Students
}

\author{
Kusen \\ Institut Agama Islam Negeri Curup \\ Corresponding Author E-mail: kusenpasca1969@gmail.com
}

Received 2 January 2022; Revised 5 February 2022; Accepted 7 March 2022

\begin{abstract}
This study aims to determine the needs of IAIN Curup postgraduate students for digital teaching materials based on MOOCs. The research sample was 105 postgraduate students from 4 study programs, namely Islamic Education Guidance and Counseling, Islamic Family Law, Islamic Education Management, and Islamic Religious Education. The research instrument used is a student needs questionnaire IAIN Curup postgraduate towards digital teaching materials based on MOOCs. The data analysis technique used is descriptive statistical analysis. The results of this study are digital teaching materials based on MOOCs are urgently needed by postgraduate students of IAIN Curup. This is evidenced by the percentage gain from the results of filling out the needs analysis questionnaire for digital teaching materials based on MOOCs, which is $87.5 \%$, which means that students strongly agree to the development. These results will have an impact on the use of technology in the development of teaching materials.
\end{abstract}

Keywords: Need Analysis, Digital Teaching Materials, MOOCs

\section{Introduction}

The development of media is now dominated by digital technology. In everyday life, students always interact with digital technology (Lilis, 2019). Indonesia also currently occupies the fifth position as a mobile internet user. The industrial revolution 4.0 which is a revolution that occurs throughout the world provides challenges as well as impacts for the younger generation and also the 
world of education in Indonesia (Wening \& Santosa, 2020). Therefore, the development of science and technology increasingly encourages renewal efforts in the use of technological results in the learning process (Pratita et al., 2021). One of them is the use of digital teaching materials. Digital teaching materials are unlimited and easily accessible learning resources and are part of electronic learning (Alperi, 2019; Faisal et al., 2020). Accessibility of content on digital teaching materials can support the learning process effectively and efficiently(Prastyo et al., 2021). Digital teaching materials can also improve students' ability to think creatively, solve problems, be critical, and be motivated. This can support the achievement of 21 st century learning goals (Dewi et al., 2021). The provision of digital teaching materials can stimulate students to learn earlier before class takes place so that students feel confident in presenting answers and expressing their opinions (Wijayanti, 2018). The benefits of digital teaching materials support the statement that learning materials must be well designed to be attractive to students (Erwin et al., 2021).

One form of innovation from digital teaching materials is digital teaching materials based on Massive Open Online Courses (MOOCs). MOOCs are here as a new model of education and learning (Risdianto et al., 2021). MOOCs use the internet to deliver lectures at the world's most prestigious universities and educational institutions, creating a revolution that has thrived since 2012 (Busri et al., 2019; Chapman et al., 2016; Lian et al., 2021; Risdianto et al., 2021). MOOC is a platform where participants engage in the learning process by sharing course information among themselves through connection and collaboration (Zhussupbekov, 2015). MOOC is an online learning course with unlimited participants and can be accessed openly through the website (Ismail et al., 2018; Risdianto, 2021). MOOCs are built on the idea that "information is everywhere", expanding access to education (Pilli \& Admiraal, 2020). MOOCs provide a wider potential for each individual to continuously equip themselves with new knowledge and skills (Rafiq et al., 2019). In principle, MOOCs describe Online Courses with a very large number of open enrollments, which provide not only administrative services but also in terms of content, design, access points, application methods and definition of success (Risdianto et al., 2021).

Based on the description above, it is important to develop digital teaching materials based on MOOCs. However, before doing the development needs analysis needs to be done. according to Utami \& Atmojo (2021), analysis of teaching material needs is the main step for developing digital teaching materials. 
Therefore, this research will analyze the need for digital teaching materials focused on postgraduate students at IAIN Curup.

\section{Methods}

This study aims to determine the needs of IAIN Curup postgraduate students for digital teaching materials based on MOOCs. The research sample was 105 postgraduate students from 4 study programs, namely Islamic Education Guidance and Counseling, Islamic Family Law, Islamic Education Management, and Islamic Religious Education. The research instrument used is a student needs questionnaire IAIN Curup postgraduate towards MOOCs-based digital teaching materials. The data analysis technique used is descriptive statistical analysis. Needs analysis is carried out on the data obtained in the form of percentages. The percentage is obtained based on a modified Likert scale calculation. With a Likert scale, the variables to be measured are translated into variable indicators. Furthermore, these indicators are used as guidelines in compiling items in the form of questions or statements. Instrument items are given a quantitative value as shown in table 1 below:

Table 1. Likert Scale Calculation

\begin{tabular}{cc}
\hline Evaluation & Scale Value \\
\hline Strongly agree & 4 \\
Agree & 3 \\
Do not agree & 2 \\
Strongly Disagree & 1 \\
\hline
\end{tabular}

The questionnaire was tested for validity and reliability using SPSS with the following conditions:

1. Valid : if rcount is greater than rtable value (rcount $>$ rtable)

2. Invalid : if rcount is less than rtable value (rcount $<$ rtable)

3. Reliable if Cronbach's alpha value $>0.60$

4. Not reliable if Cronbach's alpha value $<0.60$

(Budiwibowo \& Nurhalim, 2016)

Analysis of the results of the questionnaire was carried out quantitatively using the following formula.

$p=\frac{n}{N} \times 100 \%$ 
where $\mathrm{P}$ is the percentage of the results of the questionnaire analysis, $\mathrm{n}$ is the total score of the assessment, and $\mathrm{N}$ is the maximum possible score. For the Likert scale, the score interpretation model can be seen in table 1 .

Table 2. Likert Skala Scale Interpretation

\begin{tabular}{cc}
\hline Percentage (\%) & Category \\
\hline $0 \%-25 \%$ & Strongly Disagree \\
$26 \%-50 \%$ & Do not agree \\
$51 \%-75 \%$ & Agree \\
$76 \%-100 \%$ & Strongly agree \\
\hline
\end{tabular}

\section{Results and Discussion}

This study aims to determine the needs of IAIN Curup postgraduate students for digital teaching materials based on MOOCs. IAIN Curup is one of the state universities in Rejang Lebong Regency, Bengkulu Province.

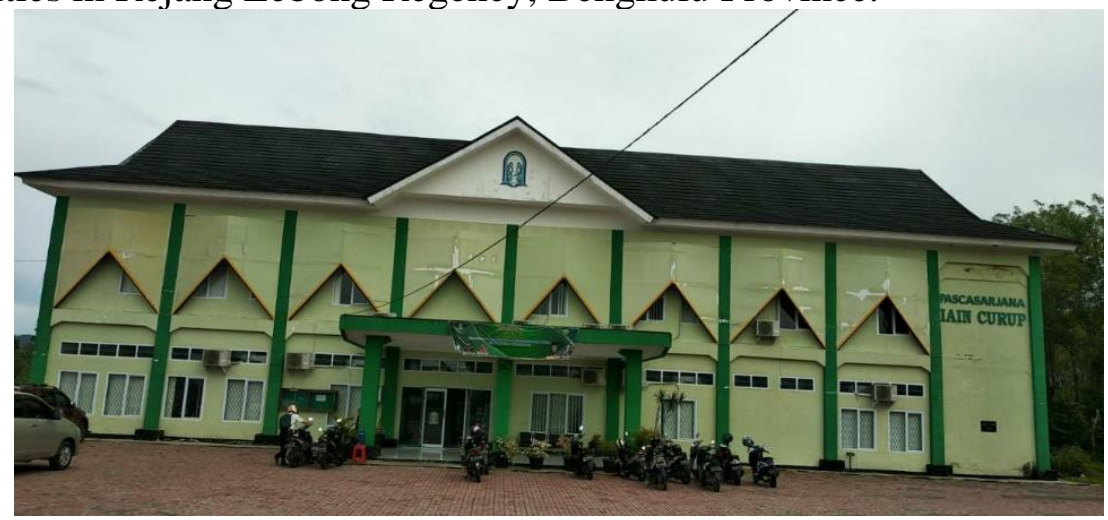

Figure 1. IAIN Curup

The data in this study were obtained from 105 students from 4 postgraduate study programs who filled out a questionnaire on the need for digital teaching materials. Prior to further analysis, the questionnaire data was used to test the validity and reliability of the questionnaire used. The following is a table of validity test results. 
Table 3. Validity Test Results

\begin{tabular}{|c|c|c|c|}
\hline No Item & r-Calculate & r-Table & Category \\
\hline 1 & 0.762797 & \multirow{22}{*}{0.1918} & Valid \\
\hline 2 & 0.801679 & & Valid \\
\hline 3 & 0.708496 & & Valid \\
\hline 4 & 0.866224 & & Valid \\
\hline 5 & 0.873125 & & Valid \\
\hline 6 & 0.810917 & & Valid \\
\hline 7 & 0.742239 & & Valid \\
\hline 8 & 0.743108 & & Valid \\
\hline 9 & 0.707951 & & Valid \\
\hline 10 & 0.662494 & & Valid \\
\hline 11 & 0.7997 & & Valid \\
\hline 12 & 0.780503 & & Valid \\
\hline 13 & 0.567506 & & Valid \\
\hline 14 & 0.820041 & & Valid \\
\hline 15 & 0.893381 & & Valid \\
\hline 16 & 0.858452 & & Valid \\
\hline 17 & 0.724218 & & Valid \\
\hline 18 & 0.77584 & & Valid \\
\hline 19 & 0.901644 & & Valid \\
\hline 20 & 0.868318 & & Valid \\
\hline 21 & 0.843927 & & Valid \\
\hline 22 & 0.781806 & & Valid \\
\hline
\end{tabular}

From the table above, it is known that all items contained in the questionnaire are valid because all of them have a t-count value greater than the t-table, which is 0.1918 . The results of the reliability test can be seen in the following table.

\section{Table 4. Reliability Statistics}

\begin{tabular}{cc}
\hline Cronbach's Alpha & N of Items \\
\hline 0.969 & 22 \\
\hline
\end{tabular}

The table above shows the results of the calculation of data reliability with 22 statement items using the Cronbach alpha method, a score of 0.969 is obtained. 
The value obtained is greater than 0.60 , then according to the rules of determining reliability, the questionnaire used in this study is said to be reliable.

After testing the validity and reliability of the questionnaire, data analysis was carried out to determine the needs of IAIN Curup postgraduate students for digital teaching materials based on MOOCs. To find out the percentage of needs development of based digital teaching materials MOOCs can be seen in table 5

Table 5. Percentage Level of Need MOOCs-Based Digital Teaching Materials

\begin{tabular}{lcccc}
\hline Respondent & $\begin{array}{c}\text { Total Score } \\
(\mathbf{n})\end{array}$ & $\begin{array}{c}\text { Maximum } \\
\text { Score (N) }\end{array}$ & $\begin{array}{c}\text { Percentage } \\
\boldsymbol{P}=\boldsymbol{x} \mathbf{1 0 0} \frac{\mathrm{n}}{\mathrm{N}} \%\end{array}$ & Category \\
\hline $\begin{array}{l}\text { 105 IAIN Curup } \\
\text { Graduate Students }\end{array}$ & 8085 & 9240 & $87.5 \%$ & $\begin{array}{c}\text { Strongly } \\
\text { agree }\end{array}$ \\
\hline
\end{tabular}

Table 5 provides information that IAIN Curup postgraduate students strongly agree with the development of MOOCs-based digital teaching materials. This is indicated by the large percentage obtained by $87.5 \%$ of the maximum percentage of $100 \%$. And according to the Likert scale interpretation table for data with a percentage of $76 \%-100 \%$ in the category of strongly agree.

There are several previous studies that are relevant to this research, one of which is research conducted by Yuliana \& Atmojo (2021). In this study, data was obtained that teachers have not developed digital-based teaching materials to facilitate students' science learning so that the development of digital teaching materials is needed. Then the research conducted byUtami \& Atmojo (2021) who obtained data that digital teaching materials were needed in supporting the success of learning and learning in elementary schools, especially science learning materials.

\section{Conclusion}

MOOCs-based digital teaching materials are urgently needed by IAIN Curup postgraduate students. This is evidenced by the percentage gain from the results of filling out the needs analysis questionnaire for digital teaching materials based on MOOCs, which is $87.5 \%$, which means that students strongly agree to the development. The results of this study can be used as a basis for further research related to the development of digital teaching materials based on MOOCs for postgraduate students of IAIN Curup. 


\section{Acknowledgment}

Thanks are due to all parties who have contributed so that this research can be completed.

\section{References}

Alperi, M. (2019). Peran Bahan Ajar Digital Sigil Dalam Mempersiapkan Kemandirian Belajar Peserta Didik [The Role of Digital Sigil Teaching Materials in Preparing Students' Independent Learning]. Jurnal TEKNODIK, 23(2), 99-110.

Budiwibowo, A. K., \& Nurhalim, K. (2016). Pengaruh Motivasi Belajar Terhadap Prestasi Belajar Warga Belajar Kejar Paket C [The Influence of Learning Motivation on Learning Achievement of Citizens Pursue Learning Package C]. Journal of Nonformal Education, 2(2), 168-174.

Busri, E., Zulirfan, Z., \& Fakhruddin, F. (2019). The Development of MOOC Media to Increase Recall Memory Skill on Physics at Vocational High School. Journal of Physics: Conference Series, 1(1), 1-4. https://doi.org/10.1088/1742-6596/1351/1/012017

Chapman, S. A., Goodman, S., Jawitz, J., \& Deacon, A. (2016). A strategy For Monitoring and Evaluating Massive Open Online Courses. Evaluation and Program Planning, 57, 55-63. https://doi.org/10.1016/j.evalprogplan.2016.04.006

Dewi, K., Sumarmi, \& Putra, A. K. (2021). Pengembangan Bahan Ajar Digital Berbasis STEM dengan Pendekatan Eco-Spatial Behavior Materi Kependudukan [Development of STEM-Based Digital Teaching Materials with an Eco-Spatial Behavior Approach for Population Materials]. J-PIPS (Jurnal Pendidikan Ilmu Pengetahuan Sosial), 7(2), 92-102. https://doi.org/10.15548/jpips.v7i2.11960

Erwin, Y., Arafat, Y., \& Wardiah, D. (2021). Pemanfaatan Information and Communications Technology Sebagai Sumber Belajar Di Era Digital [Utilization of Information and Communications Technology as Learning Resources in the Digital Age]. JMKSP (Jurnal Manajemen, Kepemimpinan, Dan Supervisi Pendidikan), 6(1), 44-51.

Faisal, M., Hotimah, Nurhaedah, AP, N., \& Khaerunnisa. (2020). Peningkatan Kompetensi Guru Sekolah Dasar dalam Mengembangkan Bahan Ajar Digital di Kabupaten Gowa [Improving the Competence of Elementary School Teachers in Developing Digital Teaching Materials in Gowa Regency]. 
Publikasi Pendidikan, Jurnal Pemikiran, Penelitian dan Pengabdian Masyarakat Bidang Pendidikan, 10, 266-270.

Ismail, M. E., Utami, P., Ismail, I. M., Hamzah, N., \& Harun, H. (2018). Development of massive open online course (MOOC) based on addie model for catering courses. Jurnal Pendidikan Vokasi, 8(2), 184-192. https://doi.org/10.21831/jpv.v8i2.19828

Lian, B., Oksatianti, B. R., Risdianto, E., \& Mayub, A. (2021). Need Analysis of MOOCs-Based Learning Media Development to Improve Student Motivation. Al-Ishlah: Jurnal Pendidikan, 13(2), 868-873. https://doi.org/10.35445/alishlah.v13i2.

Lilis. (2019). Pengembangan Bahan Ajar Digital Pada Mata Pelajaran Dasar Listrik dan Elektronika Kelas X [Development of Digital Teaching Materials in Basic Electrical and Electronics Class X]. Jurnal Teknologi Pendidikan Dan Pembelajaran, 6(1), 156-168.

Pilli, O., \& Admiraal, W. (2020). A Taxonomy of Massive Open Online Courses. Contemporary Educational Technology, 7(3), 223-240. https://doi.org/10.30935/cedtech/6174

Prastyo, E. B., Islam, M. N., \& Putra, K. (2021). Pengembangan Bahan Ajar Digital Mobilitas Penduduk Dan Ketenagakerjaan Berbasis STEM [Development of STEM-based Population Mobility and Employment Digital Teaching Materials]. Journal of Social Science and Education, 2(2), 149159.

Pratita, D., Amrina, D. E., \& Djahir, Y. (2021). Analisis Kebutuhan Mahasiswa Terhadap Bahan Ajar Sebagai Acuan Untuk Mengembangkan E-Modul Pembelajaran Digital [Analysis of Student Needs for Teaching Materials as a Reference for Developing Digital Learning E-Modules]. Jurnal PROFIT Kajian, $\quad 8(1)$, 69-74. https://ejournal.unsri.ac.id/index.php/jp/article/view/13129

Rafiq, K. R. M., Hashim, H., Yunus, M. M., \& Pazilah, F. N. (2019). Developing a MOOC for communicative english: A battle of instructional designs. International Journal of Innovation, Creativity and Change, 7(7), 29-39. https://www.researchgate.net/publication/337414726_Developing_a_MOOC _for_Communicative_English_A_Battle_of_Instructional_Designs

Risdianto, E. (2021). MOOCs Sebuah Tren Pendidikan Masa Depan [MOOCs A Future Education Trend]. Prosiding Seminar Nasional, 7-12. https://jurnal.univpgri- 
palembang.ac.id/index.php/Prosidingpps/article/view/5465

Risdianto, Eko, Wachidi, W., Riyanto, R., Alexon, A., Fathurrochman, I., \& Kusen, K. (2021). Blended Learning Model Based on Massive Open Online Courses (MOOCs) Assisted by Augmented Reality (BMA) Model as the Electronic Learning Media in the Pandemic Covid-19. AL-ISHLAH: Jurnal Pendidikan, 13(1), 228-241. https://doi.org/10.35445/alishlah.v13i1.470 Risdianto, Eko, Yanto, M., Kristiawan, M., \& Gunawan, G. (2021). Respon Guru Pendidikan Anak Usia Dini terhadap MOOCs berbantuan Augmented Reality [Early Childhood Education Teacher's Response to Augmented Reality-assisted MOOCs]. Jurnal Obsesi: Jurnal Pendidikan Anak Usia Din, 5(2), 1487-1500. https://doi.org/10.31004/obsesi.v5i2.907

Risdianto, Eko, Yanto, M., \& Yumiarty, Y. (2021). Analysis of Teacher

Candidate Responses to the Needs of Blended Learning Model Based on MOOCs and Augmented Reality. Jurnal Iqra': Kajian Ilmu Pendidikan, 6(1), 14-26.

Utami, N., \& Atmojo, I. R. W. (2021). Analisis Kebutuhan Bahan Ajar Digital dalam Pembelajaran IPA di Sekolah Dasar [Analysis of the Need for Digital Teaching Materials in Science Learning in Elementary Schools]. Jurnal Basicedu, 5(6), 6300-6306.

Wening, M. H., \& Santosa, A. B. (2020). Strategi Kepemimpinan Kepala Sekolah Dalam Menghadapi Era Digital 4.0 [Principal's Leadership Strategy in Facing the Digital Age 4.0]. JMKSP (Jurnal Manajemen, Kepemimpinan, $\begin{array}{llll}\text { Dan Supervisi } & \text { Pendidikan), }\end{array}$ https://doi.org/10.31851/jmksp.v5i1.3537

Wijayanti, P. S. (2018). Pengembangan Bahan Ajar Digital Bahasa Inggris Matematika Dengan Bantuan Videoscribe Melalui E-Learning [Development of Digital English Mathematics Teaching Materials With the Help of Videoscribe Through E-Learning]. UNION: Jurnal Pendidikan Matematika Volume, 6(2), 147-156.

Yuliana, \& Atmojo, I. R. W. (2021). Analisis Kebutuhan Bahan Ajar Digital Interaktif untuk Pembelajaran Ilmu Pengetahuan Alam Abad 21 [Need Analysis of Interactive Digital Teaching Materials for 21st Century Natural Science Learning]. Jurnal Basicedu, 5(6), 6034-6039.

Zhussupbekov, A. (2015). Moocs and Their Implications for Traditional Higher Education Institutions. Journal of University of Southampton, 29-33. 